神経ペプチドと家畜の成長ホルモン分泌に関する最近の知見

\author{
橋爪力
}

岩手大学農学部，盛岡市 020

\title{
Recent Advancement in Neuropeptides induced Growth Hormone Secretion in Domestic Animals
}

\author{
Tsutomu Hashizume \\ Department of Bioscience and Technology, Faculty of Agriculture, \\ Iwate University, Morioka-shi 020
}

Key words : neuropeptides, growth hormone, domestic animals

\section{はじめに}

成長ホルモン $(\mathrm{GH})$ の分泌は $\mathrm{GH}$ 分泌促進因子であ る成長ホルモン放出ホルモン (GHRH) 之GH 分泌抑制 因子であるンマトスタチンにより二元的に支配さ机てい $3^{18,20.40,45,47,50,104,150)}$. GH 分泌汇関係する GHRH とソマ トスタチンは主として視床下部の马状核と脳室周国核に それぞれ神経細胞体を持つGHRH ニューロンとソマト スタチンニューロンにより生産される ${ }^{40,45,47,88,104,150)}$ 。こ れらのニューロンは正中隆起に投射されており，下垂体 門脈の第一次血管叢内に放出された GHRH とンマトス タチンは，門脈を介し下垂体まで運搬され下垂体前葉の $\mathrm{GH}$ 細胞の細胞膜上に存在する各々の受容体と結合して GH の合成上分泌を調節する GHRH ニューロンとソマトスタチンニューロンは神経 伝婵物犋等を介してさらに高位の中枢により支配され $3^{18,20,40,104,150)}$. 下垂体からの $\mathrm{GH}$ 分泌は末梢血中の $\mathrm{GH}$ やインスリン様成長因子 (IGF)-1，グルココルチコ1 ド，甲状腺朳ルモン，エストロシェン，テストステロン 等のホルモンにより修飾されるが,グルコース, 遊離脂 肪酸，アルギニン等の代謝性因子も $\mathrm{GH}$ の分泌を修飾す
$3^{18,20,40,45,50,104,150)}$. しかし，これらの修飾因子がどのよ うな機序で $\mathrm{GH}$ 分泌を变化させるかについてはよく分 加ていない.

GHRH ニューロンとソマトスタチンニューロンの存 在する視床下部には多くのペプチドが存在する゙13).これ らのペプチドは神経柔で生産さ机る生理活性ペプチドで 神経伝達物質ととあにシナブスにおける神経伝達に重要 な役割を演じていると考えられている．神経ペプチドは いくつかのグループに分けられるが(表1)、ラットでは これらの神経ペプチドは脳内の 135 もの神経核に存在す る(13). 神経ペプチドの GH 放出に及に゙す影響は主として ラットやヒトで検討されてきた18,45, 104, 150)，一般的にこれ らのペプチドは視床下部の GHRH とンマトスタチン ニューロンを介してGH 分泌を修飾すると考えられる が、視床下部より上位または下位の中枢レベルで，さら に待下垂体レベルです GH 分泌を修飾することが考元 られる、本稿では多くの神経ぺプチドの中から GHRH とソマトスタチン以外で GH 分泌に影響を及ばすと思 われるぺプチドに焦点をあて，著者らがウシやヤギで行 なった結果を紹介しながら複雑な $\mathrm{GH}$ 放出機構の一端 を述べる. GHRH とソマトスタチン等の総論に関して 
橋爪

Table 1. Classification of neuropeptides

\begin{tabular}{ll}
\hline A. Hypothalamic neuropeptides & D. Gastrointestinal peptides \\
LHRH & Substance P \\
TRH & Substance K \\
CRH & NPY \\
GHRH & VIP \\
Somatostatin & PHI-27 \\
Vasopressin & CCK \\
Oxytocin & Bombesin \\
B. Pituitary neuropeptides & Secretin \\
LH & Motilin \\
TSH & Galanin \\
GH & Glucagan \\
Prolactin & Insulin \\
ACTH & E. Other neuropeptides \\
$\alpha$-MSH & Neurotensin \\
$\gamma-$ MSH & Angiotensin II \\
C. Opioid peptides & PACAP \\
$\beta$-endorphin & Bradykinin \\
Enkephalin congeners & DSIP \\
Dynorphin congeners & FMRFamide \\
& CGRP \\
& Ranatensin \\
& ANP \\
\hline
\end{tabular}

Hypothalamic neuropeptides are present in highest concentrations in the hypothalamus and are known as releasing or release-inhibiting hormones. Pituitary neuropeptides were identified originally in the anterior pituitary but are also synthesized by nerve cells in several regions of the CNS. There are three families of opioid peptides in the brain, each formed from its own precursor molecule. Gastrointestinal peptides were identified originally in secretory cells in the mucosa of gastrointestinal tract or pancreas. Other neuropeptides are those that do not fit into the previous groups. (Modified from PaLKovits ${ }^{113}$ )

は、多くの絵説があるので, 他書18, 20,40, 15, 47,50,66, 75, 104,114, 1503 に譲ることにする。

\section{1.甲状腺刺激ホルモン放出ホルモン（TRH）}

TRH は豚の視床下部加ら単離されたアミ，酸残基 3 個からなるぺプ手ド133)であるが，甲状腺刺激ホルモン だけではなく，GH やプロラクチン（PRL）の放出も刺 激する $32,72,81,139)$. GHについてはヒト，ウシ，ヒッジ， ラットのほか, 鳥類, 爬虫類, 両生類でも放出を刺激す る55. ウシでは in vitro下で下垂体細胞から GH を放出 させるが，その放出量はPRL に比べるとはるかに少な い:39，GHRH 存在下での TRHに対するGH の放出反 応には喠差が認められ，ウシ下重体細胞では GH の放出 を刺激するが，七ッジ下垂体細胞では抑制する54)。また
TRH とGHRHをウシ下垂体細胞に同時に作用させた 時のGH放出は相乗的に増加する ${ }^{68)}$. In vitro下での ラット下垂体細胞では，TRH に対するGH の放出反応 は認められず，またTRHはVIPにより誘起した GH 分 泌老抑制する39)．下垂体細胞からの TRHによる GH 放 出機構は $\mathrm{Ca}^{2+} に$ 依存するが, サイクリック $\mathrm{AMP}$ (cAMP) に上万機構を介さない" ${ }^{1523}$. In vivo では TRH の静脈および皮下注射はウシの血中 GH 濃度を急速に 上昇させる ${ }^{32,72,81)}$ 。またウシで TRH はヒトGHRHに比 ベ $\mathrm{GH}$ 放出效果は弱いが65)，両ぺプチドを静脈内に同時 投与すると $\mathrm{GH}$ 放出が相乗的に壃加する ${ }^{65,86)}$. In vitro に比べて in vivoでTRHによるGH放出効果が大きい ことから，ウシでは TRH の GH 放出作用は下垂体への 直接作用と視木下部を介する作用の二つの機構があるむ 
のと思われる.

\section{2. オピオイドペプチド}

オピオイドペプチド（オピオイド）は視床下部や下垂 体に当存在し，下垂体前葉ホルモンの神経内分泌謂節に 関係していることが示睃されている ${ }^{38)}$. GHに関しては

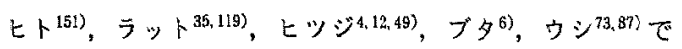
オピオイドを全身投与あるいは脳室内投与する之 $\mathrm{GH}$ 分泌が刺激される.すなわち，ヒトではエンケファリン の誘導体は GH 分泌を刺激する ${ }^{151}$. またラットでは $\beta-$ エンドルフィンやメチオニンエンケファリンの誘導体は $\mathrm{GH}$ 分泌增加をもたらす ${ }^{35,1199}$. ヒッジでは $\beta$ ーエンドル フィンやエンケファリンの誘導体は $\mathrm{GH}$ 分泌を刺激す $3^{4,12,49)}$.ブタやウシではモルフィネの脳室内投与は $\mathrm{GH}$ 分泌を刺激する ${ }^{6,87)}$.またえピオイドのアゴニストをウ シに静脈内投与すると血中の $\mathrm{GH}$ は增加する ${ }^{73)}$. しかし ながら，この上うなオピオイドの $\mathrm{GH}$ 放出刺激効果は才

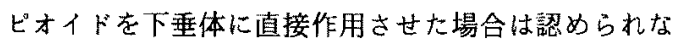
い20).オピオイドの GH 分泌堌加はラットでは抗ソマト スタチン抗体では阻害されず27, 抗 GHRH 抗体の前投 与により阻止されるので98，オピオイドの GH 放出刺激 効果はソマトスタチンよりGHRH を介した機構に依存 すると考えられる、オピオイドの GH 放出機構には $\alpha-$ アドレナリン作動性機構43,77,98) や GABA 作動性機構76) が関与している可能性がラットで示されている.

\section{3. サブスタンス P}

サブスタンス $\mathrm{P}$ はウマの脳と腸管から見い出された アミノ酸残基 11 個からなるポリベプチドである22. こ のペプチドはラットやヒトでは視休下部をはじめ脳内の さまざまな部位に存在することが報告されている74,85). サブスタンスPはラットで GHやPRLを放出させ $3^{78,120,163)}$.すなわ方, ウレタン麻酥下でのサブスタンス $\mathrm{P}$ の静脈内投与は $\mathrm{GH}$ 之 $\mathrm{PRL}$ を增加させる ${ }^{78,120)}$ 。また 脳室内に 0.5 およで $2.0 \mu \mathrm{g}$ のサブスタンス $\mathrm{P}$ を投与する と 5 分以内に $\mathrm{GH}$ が上昇し，この濃度仙 1 時間持続す $ろ^{169)}$. サブスタンス $\mathrm{P}$ の GH 放出作用は in vitroでは認 められないので163)，この作用は視床下部を介した作用で あると考元られる。しかし，サブスタンス $\mathrm{P}$ は in vitro でラット視㦿下部からソマトスタチンを放出させるの で134), サブスタンス PのGH 放出機構は複雑であると 推察される。

\section{Neuropeptide Y (NPY)}

NPY はブタの脳から単離された 36 個のアミ/酸残基
からなるポリペプチドである ${ }^{155) . ~ N P Y ~ は ラ ッ ト 29) や ヒ ~}$ ${ }^{30)}$ の視庆下部では GHRH ニューロン内にも存在した

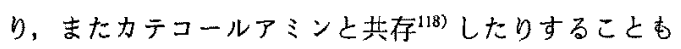
報告されている。したがって，NPY は GHRH やソマト スタチンの放出を調整して GH の分泌を修飾している 可能性が考えられる.NPYはラット下垂体細胞加ら $\mathrm{GH}$, 黄体形成ホルモン (LH), 贸胞刺激ホルモン (FSH) を直接放出させるが，脳室内投与した場合は， $\mathrm{GH}$ 分泌は抑制される ${ }^{96)}$ ， 七下下垂体細胞では $\mathrm{GH}$ の基 碟濃度や GHRH で誘起された GH 分泌を減少させる゙。

\section{Vasoactive intestinal polypeptide (VIP)}

VIP は 28 個のアミノ酸残基からなり，ブタ十二指腸 粘膜加ら血管拡張作用をむつぺプチドとして策離され た ${ }^{123)}$ VIPはブタ,イヌ、ラット, マウスおよびヒトの 脳および下垂体に広く分布し ${ }^{44,125,126)}$ ，その受容体は脳内 のさまざまな部位に見い出されている108, 126)。視床下部 に存在するVIP 細胞の一部は正中隆起に終末する ${ }^{137}$. またVIPはラットの下垂体門脈血中にも存在す $ろ^{124.135)}$.これらの事奏は，VIP は下垂体前枼ホルモンの 分泌調節機構に関与している可能性を意味する、VIP は ラットやとトでは $\mathrm{GH}^{11,39,80,95,162)}$ のみならず $\mathrm{PRL}^{77,162),}$ LH ${ }^{162)}$ の放出る刺激する。VIP はラットで視床下部を介 して GH 放出させると報告されたが的，末端肥大症患 者では in vivo のみならず， in vitro 下で下垂体前葉細胞 加ら GH 直接放出させる にグルココルチコイドを作用させるとVIP の GH 放出

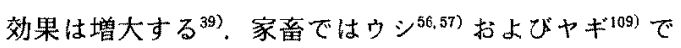
VIP は下垂体に直接作用してGH を放出させる。しか し, GHRH とVIP のウシ下垂体細胞からの GH 放出効 果を比較して見ると，VIPは $10^{-8} \mathrm{M}$ までしか $\mathrm{GH}$ を放 出させないのに対し，GHRH は $10^{-11} \mathrm{M}$ まで GH を放出 させること年，また GHRH 作用後の GH放出時間は VIPに比べ極辱いので (図 1), VIPの GH 放出効果 はGHRHに比べ弱いことが推察される. GHRHのGH 放出効果はVIPより強力であることはラットでも報告 されている゙99. GHRHとVIPは CAMPを介してGHを 放出させるが'13.45.125)，GHRH が VIPに比べ強力なのは GHRH には GH 細胞の分化, 成長, 堌殖, ならびに $\mathrm{GH}$ 遗伝子の転写促進作用 ${ }^{45)}$ があるた古推察される。VIP の GH 放出作用はVIP と GHRH の構造が比較的近いか らと考えられる ${ }^{125)}$. VIP で誘起されたウシ GH の放出 はGHRH と同様にンマトスタチンにより挪制され $3^{142)}$. 

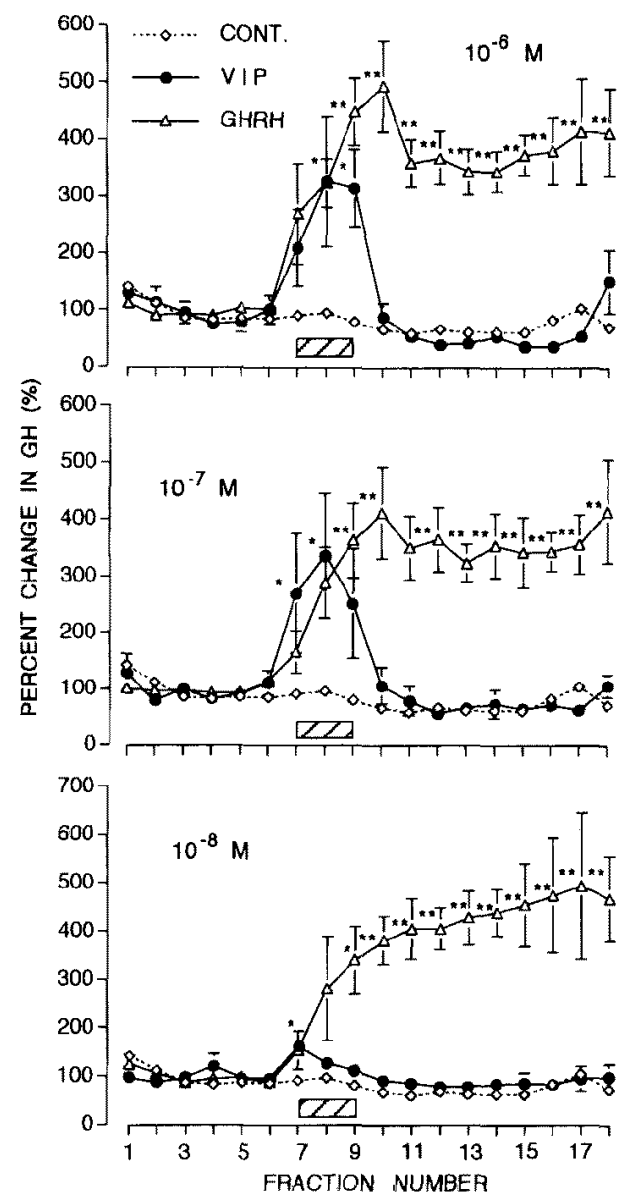

Fig. 1. GH changes in the effluents from bovine pituitary explants perifused with the media con-taining $10^{-6}, 10^{-7}, 10^{-8} \mathrm{M}$ VIP and GHRH (hpGRF (1-29)- $\mathrm{NH}_{2}$ ) for $30 \mathrm{~min}$. Each effluent was collected at $10 \mathrm{~min}$ intervals at a flow rate of $18 \mathrm{ml} / \mathrm{hr}$. The mean GH concentration of 6 fractions collected during $1 \mathrm{hr}$ before VIP or GHRH perifusion was taken as basal control value. Values during the experiment were calculated as percent changes from the basal control value. Each value represents the mean \pm $\mathrm{SE}$ of 5 experiments. Significant changes from the basal level of the control group were indicated by asterisks ( $\left.\mathrm{P}<0.05,{ }^{* *} \mathrm{P}<0.01\right)$. The period perifused VIP or GHRH is denoted by hatched bar. (HASHIZUME and KANEMATSU ${ }^{57)}$ )

\section{Peptide histidine isoleucine (PHI)}

PHIはブタの十二指腸から䍩離された 27 個のアミノ
酸残基からなるぺプチドである ${ }^{1544}$. PHI はVIP類似の ペプチドで，アミノ酸構造はVIPと $48 \%$ 一致する ${ }^{(54)}$. また両べプチドの前駆体は同一物質であることも知られ ている ${ }^{69}$. PHI は視床下部にも存在し157)，ラット下垂体

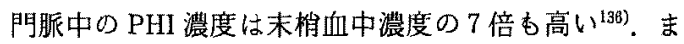
たPHI とVIP は正中隆起から下垂体門脈血中に同時に 放出される(136).ラットでは PHIのアミ，酸構造は GHRH と $52 \%$ 一致する ${ }^{146)}$. ラット下垂体細胞を用いた in vitro 実験系では，デキサメサゾンの存在下で PHI は $\mathrm{GH}$ を放出させるる 梁で PHI $\left(10^{-14} \sim 10^{-7}\right)$ O GH 放出効果は観察されな $\left(1^{142)}\right.$.

\section{7. コレシストキニン（CCK）}

CCK は胆衰収縮作用之脺消化醉素放出作用を持つぺ プチドとして腸絬膜から単離された。 CCKには湔駆体 のプロセッシングから生じるアミ/酸残基数の異なった ペプチドが湿在し,これらには CCK-4, CCK-8, CCK12, CCK-33，CCK-39，CCK-58などがある. CCK は消 化管のみならず中枢神経系にも広く分布する $\mathrm{CCK}$ の生物活性は C 末端に位置する8個のアミノ酸加 らなる部分 (CCK-8)によって発現する ${ }^{158)}$ 。また脳内に 存在する CCK の $70 \%$ はCCK-8であり ${ }^{41)}$, 神経伝達物 質あるいは調節物質として作用していると考えられてい $3^{168)}$. CCK は視床下部に広範に存在するが，下垂体門 脈血中や下垂体にも見い出されている の受容体は視枺下部のみならず, 下垂体にも存在す

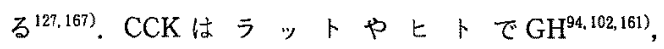
$\mathrm{LH}^{\mathrm{82}, 102,161)}, \mathrm{PRL}^{93,153,161)}$ 等の下垂体ホルモンの分泌に関 与していることが報告さ机ている。ラットではCCK-8 を脳室内に投与すると血中 $\mathrm{GH}$ 㿯度は上昇するが, in vitroでは半切した下垂体細胞からの GH 分泌は認めら れない活1. また静脈内投与では血中 $\mathrm{GH}$ 濃度が増加する 報告 ${ }^{94)}$ としない報告(161) がある。培養正常下垂体細胞を 用いた実験系では CCK-8 $\left(10^{-11} \sim 10^{-7} \mathrm{M}\right)$ は GH 分泌 を用量依存的に増加させる ${ }^{94)}$. また下垂体腫瘍 $\mathrm{GH}_{3}$ 細胞

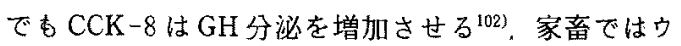
$\dot{8}^{58)}$ およびヤギ597 でCCK-8 は下垂体に直接作用して $\mathrm{GH}$ を放出させる。しかしヒッジを用いた奏験では CCK の脳室内投与は GH の放出を抑制した之報告されてい $ろ^{144)}$.

\section{Motilin}

Motilin はブタの十二指腸から単離された 22 個のア ミ／酸残基からなるポリペプチドである(7)，Motilinは 
ラットの脳内にも見い出され 正中隆起には Motilin $z^{2}$ 高濃度に存在する(107)。ラットの 下垂体前葉細胞の培養系では用量依存的に $10^{-9} \mathrm{M}$ まで GH を放出させる ${ }^{128)}$. Motilinのラット静脈内投与は血 中 GH 濃度を增加させる. また Motilin の抗血清投与は 血中 GH 濃度を減少させる。しかしラット第三脳室内一 の Motilinの投与は GH 分泌を抑制するので'29), Motilinは下垂体レベルでは $\mathrm{GH}$ 分泌に促進的に作用 し，中枢レベルでは $G H$ 分泌を抑制すると考えられる。

\section{9. ガラニン}

ガラニンはブタの小腸より単離された 29 個のアミ 酸残基よりなるペプチドである ${ }^{156)}$.ガラニンは消化管の

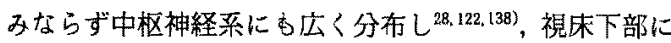
あるガラニン産生ニューロンは正中隆起外層に終末す る ${ }^{122)}$.またガラニンは下垂体にあ存在する28).さらに， サルでは GHRH とガラニンは視床下部の弓状核の細胞 体に共存していることも報告されている77. ガラニンは

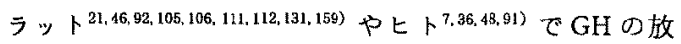
出を刺激する。すなわち，ガラニンの脳室内投

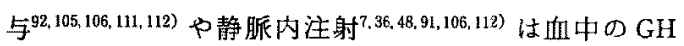
濃度を增加させる．ガラニンはin vivoで $\mathrm{GH}$ を放出さ せたが，下垂体細胞にガラニンを直接作用させた場合に は GH 放出させなかったので21.111.112)，視床下部を介し た作用であると報告された．しかし，その後下垂体細胞 に直接作用して GHを放出させることる報告さ れ46,131, 1599)，ガラニンの GH 放出機構には視床下部を介す る作用の他，下垂体細胞に直接作用する機構もあること が示された．ヒトではガラニンと GHRH を同時投与す る之, GHRH 単独投与時に比へ，血中の GH 濃度は 3 倍 に堌加するる36).またガラニンによる $\mathrm{GH}$ 分泌はエストロ ジェンレベルに関係する ${ }^{48}$. ラット第三脳室内へのガラ ニン抗血清の投与は $\mathrm{GH}$ パルスの振幅を減少させ, パル スの頻度を增加させる ${ }^{92)}$. GHRH の抗血清投与は, ガラ ニン投与による $\mathrm{GH}$ 放出を抑制する ${ }^{105,1: 66)}$. またガラニ ンで誘起された $\mathrm{GH}$ の放出はンマトスタチンの投与に より抑制される36). In vitroではガラニンはラット正中 隆起からの GHRH とソマトスタチン分泌を刺激する゙3. ラット下垂体細胞にガラニンと GHRH を同時に作用さ せると，GH 放出は両ぺプチドによる相乗效果が認めら れる(6). またガラニンの下垂体細胞加らの GH 放出機構 はCAMPを介さないことも報告されている131)。家畜で はウシでガラニンは下垂体に直接作用して GH を放出 させたことが報告されている60).

\section{0. アンジオテンシン II（ANG II）}

ANG II は血圧上昇作用や飲水促進作用等有する 8 個のアミ/酸残基からなるぺプチドである(16). ANG II は血中の糖蛋白質であるアンジオテンシノーゲンからレ ニンと変換酵素により合成されるが，脳内では血中と独 立したレニンーアンジオテンシン合成系が存在する゙ ${ }^{16)}$. ラットでは ANG II は視床下部 ${ }^{80,90)}$ や下垂体 ${ }^{158)}$ にも存 在する.またラットではANG II の受容体は下垂体前

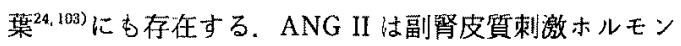
(ACTH $)^{2,23,37,16)}$ やバゾプレッシン116) の分祕を刺激す

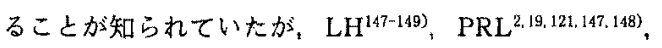
$\mathrm{GH}^{121,147.148)}$ の分泌に李関与していることが報告されて いる．GHに関しては七トで ANG II の静脈内注入は血 中 $\mathrm{GH}$ 濃度を上昇させる ${ }^{37}$. 卵巣除去ラットでは ANG II の脳室内お上び静脈内投与は GHを抑制させるが, ANG II in vitro下で下垂体に直接作用させた場合は $\mathrm{GH}$ 增加させるる(17). エストロジェン処置した即巣除去 ラットです ANG II の脳室内および静脈内投与は GH を 抑制させる ${ }^{148)}$.In vitro ではデキサメサゾンは ANG II で誘起された GH 放出を增強させるる ${ }^{(21)}$. また5〜25日齢 のラット下垂体ではデキサメサゾンの存在により ANG II による GH 放出効果は高まるが，成熟ラットの下垂体 では逆に $\mathrm{GH}$ は抑制する(21).デキサメサゾンの存在下で ANG II とGHRH 加同時添加されるとGHの放出は相 乗的に增加する ${ }^{121)}$. しかし，ラット下垂体細胞に ANG II 孝直接作用させても GH は放出しないとの報告す見ら れる2.199．家音ではウシでANG II は下垂体前葉細胞に 直接作用して GH 在放出させるが，この放出はソマトス タチンにより抑制される ${ }^{143 !}$ 。また ANG II と GHRHを 下垂体前葉細胞に同時に作用させた場合，濃度の組み合 わせによっては両ペプチドによる相加効果が観察され $3^{143)}$.

\section{Pituitary adenylate cyclase-activa- ting polypeptide (PACAP)}

PACAP は 38 個のアミノ酸残基加らなり、ヒッジの 視床下部汃ら下垂体のアデニル酸シクラーゼを活性化す るペプチトとして最近単離された ${ }^{99}$. PACAP 38 のアミ ノ酸配列はVIPと68\%が同じであるが，そのアデニル 酸シクラーゼ活性化作用はVIPの1,000倍以上も高 (99).PACAP 38 少単離された翌年に，C束端のアミノ 酸 11 個が欠如した 27 個のアミ／酸残基からなる PACAP 27 が単離され，PACAP 27 々 38 は同様の生理 活性を持つことが明らかにされた100).PACAPの神経細 胞体は視床下部の空傍核と視索上核にあり，その神経線 
維は正中隆起の外層および内層, さらに法下垂体柄の近 くに終末する ${ }^{83.164)}$ ．またPACAP の受容体は下垂体前葉 や視㦿下部にもるられる 胞, LH 細胞, PRL 細胞, ACTH 細胞, TSH 細胞などに みられる ${ }^{165)}$. PACAP の受容体は GHRH の受容体と異 なることあ証明されている゙1)。またPACAPはアデニル 酸シクラーゼを活性化するばかりか，ホスホリパーゼC 屯活性化することが最近報告されている゙146).PACAPは

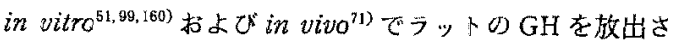
せるが、ラットでは $\mathrm{LH}^{34,99.10)}, \mathrm{PRL}^{71.99)}, \mathrm{ACTH}^{999}$ の放 出にも関与していることが報告されている。PACAPは $\mathrm{GH}$ を放出させる細胞の数を增加させるば汃りか, 細胞 一個当たりの $\mathrm{GH}$ 放出量屯增加させる 成も刺激する ${ }^{160)}$. 家畜ではウシ下垂体細胞にPACAP を直接作用すると図 2 に示すように $\mathrm{GH}$ と LH が放出 する ${ }^{61)}$. しかしPACAP $の \mathrm{GH}$ 放出作用は GHRHに比 べるし弱い622。.またPACAPで誘起された $\mathrm{GH}$ 分䎵は GHRH の場合と同様にソマトスタチンにより抑制され $ろ^{62)}$. PACAP と GHRHを下垂体細胞に同時に作用さ せると濃度の組み合わせによっては両べプチドによる $\mathrm{GH}$ 放出の相加効果が見られる PACAP の頸動脈内投与嵮中の $\mathrm{GH}, \mathrm{PRL}, \mathrm{LH}$ 濃度を 変化させないが, 脳窒内投与では GH と PRL 濃度を減 少させるとともに, 平均 $\mathrm{LH}$ 濃度と $\mathrm{LH}$ パルス頻度を減 少させる⿸丆口广 ${ }^{132)}$.

\section{GH-releasing peptide (GHRP)}

GHRP はメチオニンエンケファリンの誘導体から構 造エネルギーを計算し， GH 分泌促進活性を行なって合 成されたアミ，酸残基 6 個からなるぺプチドであ $ろ^{5.14,101,130)}$. この人工的に合成されたぺ゙チドが内在す るか否かについてはよく分かっていないが, GHRP の受 容体は下垂体之視床下部に存在 ${ }^{31)}, \mathrm{GH}$ を特異的に放 出させる ${ }^{14,67)}$ 。また最近この GHRPのアミノ酸残基の一 部を变化させた新しいGHRPも合成されている

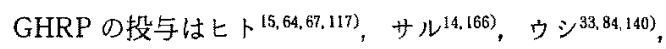

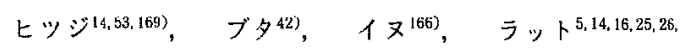
101, 130,166)，ニワトリ11)など種々の動物で $\mathrm{GH}$ を放出させ

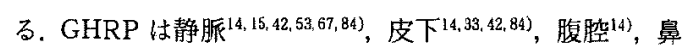
内年投与のほか，サル，イヌ、ラットでは経口投与 ${ }^{166)}$ に よっても GH を放出させる、GHRPはGHRH と異な り，下垂体細胞内の cAMP を增加させず25)，プロテイン キナーゼC を活性化して GH 分泌を促進する ${ }^{26,117)}$ ， し かし，GHRPはGHRHで誘起された下垂体細胞内の CAMP の增加を高めることも報告されている25).GHRP
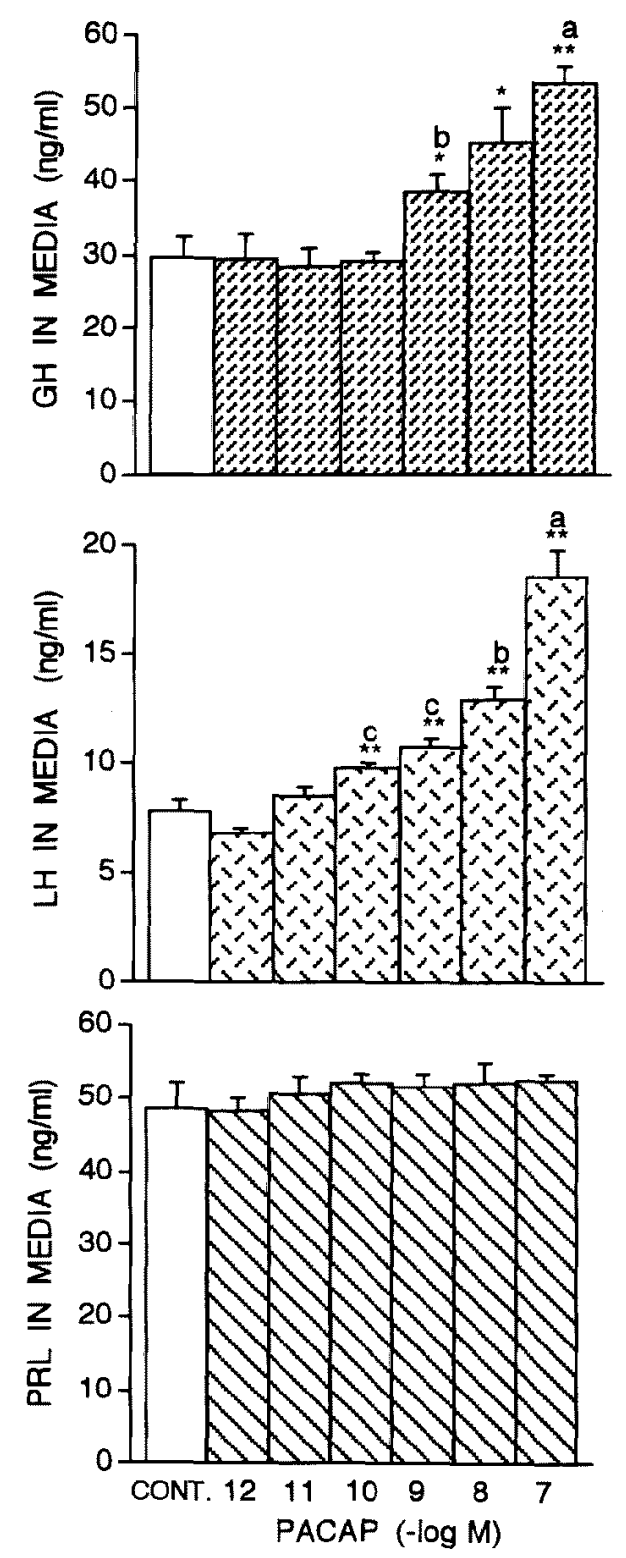

Fig. 2. Effects of PACAP on the release of $\mathrm{GH}_{1}$ $\mathrm{LH}$ and PRL from cultured bovine anterior pituitary cells in vitro. Each value represents the mean of eight determinations $\pm S E$ from three anterior pitu-itaries. Significant differences from control (CONT.) are indicated by asterisks $\left({ }^{*} \mathrm{P}<\right.$ $\left.0.05,{ }^{* *} \mathrm{P}<0.01\right)$. The different letters $(\mathrm{a}, \mathrm{b}, \mathrm{c})$ on the bar denote significant differences $(P<0.01)$. (HASHIZUME et al..$^{61)}$ ) 
とGHRHを in vitroでラット 16,25.130) やヒッジ169), 七 ト17)の下垂体細胞に同時に作用させると，雨ぺプチド による GH 放出の相加効果が観察される，ヒトでは in vivoで両ペプチドによる GH 放出の相乗効果が観察さ れる ${ }^{15)}$. GHRP は下垂体に直接作用する系5,16,25,26, 101, $117,130,140,169)$ と視床下部を介する系の二つの機構を介して $\mathrm{GH}$ を放出させる ${ }^{53)}$. ヒッジでは GHRP の静脈内投与は 下垂体門脈血中のソマトスタチン濃度には影響しない が，GHRH 濃度を増加させる ${ }^{53)}$. ヒトで GHRP を静脈 内に注射すると血中 GH の増加は GHRH と同程度の大 きさと持紿時間を示すが ${ }^{15)}$ ， ラットやヒッジの下垂体細 胞にGHRP とGHRHを宣接作用させた場合のGH放

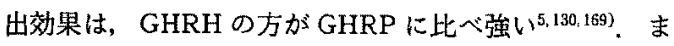
た，GHRP で誘起された GH 放出はソマトスタチンによ り抑制される年1417,140). 末成熟ラットに1日1〜2回

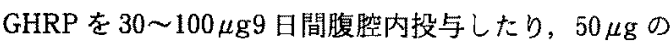
GHRPを 25 日間皮下投与すると有意に体重が增加す る ${ }^{14)}$. ウシでは GHRPを 10〜 500 $\mu \mathrm{g} / \mathrm{kg}$ 皮下注射する

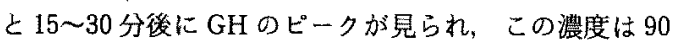
分以内に基礎值に戻る84. またウシに GHRP を投与す ると乳生産が高まること6報告されている397.GHRPは ウシの下垂体前葉細胞静㯰培養系では $10^{-11} \mathrm{M}$ まで $\mathrm{GH}$ を放出させる

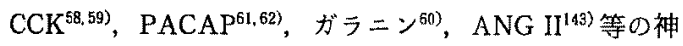
経ペプチドに比べると強いが，GHRH ${ }^{52)}$ に比べると弱 W.

\section{おわりに}

GH 分必化 GHRH とソマトスタチンにより支配され るとの概念はむはや古典的であり，GH の行泌機構には さまざまな因子が関係し，GH 分汹を修飾する，本稿で 述べてきた神経ペプチドも家畜における $\mathrm{GH}$ 分泌修飾 因子の 1 つに挙げられる. 神経ペプチドの家音における 作用を著者らがウシで行なった結果から推察すると，そ の1つに視床下部を介さず下垂体前葉細胞に直接作用し て GH の放出を刺激する作用が挙げられる年-63.109,140-143). この作用は GHRHに比べ弱かったが57.62), いくつかの 神経ペプチドは GHRH 不在下での GH 放出因子しして 㗢くと考えられた，またペプチドによってはGHRHと 共存したときに GH 放出に対する相加効果を示し，GH 分泌を修飾した ${ }^{63,143)}$ ，神経ペプチドによる GH の放出効 果はGHRH と同じようにソマトスタチンにより抑制さ れたが56,59,60,62,109,140-143)，ソマトスタチン存在下でもぺプ チドによっては GHRH との共存により GH放出への相 加效果が認められた ${ }^{140-143)}$. 著者らの研究では, 視床下部
を介しての神経ぺプチドのウシにおける作用については 明らかにされなかったが、ラットと同様にGHRH ニューロンあるいはソマトスタチンニューロンを刺激し て GH 分必を修飾していることが推祭される，また中枢 神経系の複雑なネットワークでは異なったペプチドが異 なった部位で作用していることも予想され，これらのこ とを家音で明らかにするためには，種々の所究方法を組 み合わせた総合的な解析がさらに必要よなろう。

謝辞

本稿をまとめるにあたり，ご校閲を睗った岩手大学農 学部兼松重任教授に対し，心より感謝の意を表する。

文献

1) Adams EF, Venetikou MS, Woods CA, Lacoumenta S, Burrin JM. Neuropeptide Y directly inhibits growth hormone secretion by human pituitary somatotropic tumours. Acta. Endocrinol. (Copenh.) 115 : 149-154. 1987.

2) Aguilera G, Hyde CL, Catt KJ. Angiotensin II receptors and prolactin release in pituitary lactotrophs. Endocrinology, 111 : 1045-1050. 1982.

3) Aguila MC, Marubayashi U, McCann SM. The effect of galanin on growth hormone-releasing factor and somatostatin release from median eminence fragments in vitro. Neuroendocrinology, $56: 889-894.1992$.

4) Armstrong JD, Spears JW. Changes in growth hormone and luteinizing hormone following acute or chronic administration of an opioid agonist, FK33-824, in wethers. J. Anim. Sci., $69: 774-781.1991$.

5) Badger TM, Millard WJ, McCormick GF, Bowers CY. Martin JB. The effects of growth hormone (GH)-releasing peptides on $\mathrm{GH}$ secretion in perifused pituitary cells of adult male rats. Endocrinology, 115 : 1432-1438. 1984.

6) Barb CR, Kraeling RR, Rampacek GB. Endogenous opioid peptide (EOP) modulation of growth hormone (GH) secretion in the gilt. J. Dairy Sci., 72 (Supp. 1) : 330-331. 1989.

7) Bauer FE, Ginsberg L, Venetikou M, MacKay DJ, Burrin JM, Bloom SR. Growth hormone release in man induced by galanin, a new hypothalamic peptide. Lancet., 2 : 192-194. 1986.

8) Beinfeld MC, Meyer DK, Brownstein MJ. Cholecystokinin octapeptide in the rat hypothalamo-neurohypophysial system. 
Nature, $288: 376-378.1980$.

9) Beinfeld MC, Meyer DK, Eskay RL, Jensen RT, Brownstein $\mathrm{MJ}$. The distribution of cholecystokinin immunoreactivity in the central nervous system of the rat as determined. by radioimmunoassay. Brain Res., $212: 51-57$. 1981.

10) Beinfeld $\mathrm{MC}$, Palkovits $M$. Distribution of cholecystokinin (CCK) in the hypothalamus and limbic system of the rat. Neuropeptides, 2 : 123-129. 1981.

I1) Bluet-Pajot M-T, Mounier F, Leonard J-F, Kordon C, Durand D. Vasoactive intestinal peptide induces a transient release of growth hormone in the rat. Peptides, $8: 35-38.1987$.

12) Bolton JE, Roud HK, Redekopp C, Livesay JH, Nicholls MG, Donald RA. Effects of enkephalin analogue (DAMME) on pituitary and pancreatic function in sheep. Horm. Metab. Res., 15 : 165-176. 1983.

13) Borghi C, Nicosia S, Giachetti A, Said SI. Vasoactive intestinal polypeptide (VIP) stimulate adenylate cyclase in selected areas of rat brain. Life Sci., 24 : 65-70. 1978.

14) Bowers CY, Momany FA, Reynolds GA, Hong $A$. On the in vitro and in vivo activity of a new synthetic hexapeptide that acts on the pituitary to specifically release growth hormone. Endocrinology, 114 : 1537-1545. 1984.

15) Bowers CY, Reynolds GA, Durham D, Barrera CM, Pezzoli SS, Thorner MO. Growth hormone $(\mathrm{GH})$-releasing peptide stimulates $\mathrm{GH}$ release in normal men and acts synergistically with GH-releasing hormone. J. Clin. Endocrinol. Metab., $70: 975-982.1990$.

16) Bowers CY, Sartor AO, Reynolds GA, Badger TM. On the actions of the growth hormonereleasing hexapeptide, GHRP. Endocrinology, 128 : 2027-2035. 1991.

17) Brown JC, Mutt V, Dryburg JR. The further purification of motilin, a gastric motor activity stimulating polypeptide from the mucosa of the small intestine of hogs. Can. J. Physiol. Pharmacol., 49 : 388-405. 1971.

18) Buonomo FC, Baile CA. The neurophysiological regulation of growth hormone secretion. Domest. Anim. Endocrinol., 7 : 435-450. 1990.

19) Canonico PL, MacLeod RM. Angiotensin peptides stimulate phosphoinositide breakdown and prolactin release in anterior pituitary cells in culture. Endocrinology, $118: 233-238.1986$.

20) Casanueva FF. Physiology of growth hormone secretion and action. Acromegaly, $21: 483-517$.
1992.

21) Cella SG, Moiraghi V, Carcano F, Torsello A. Growth hormone (GH)-releasing effect of galanin : Mechanism of action. Pharmacol. Res. Commun., 19 : 977-978. 1978.

22) Chang MM, Leeman SE. Isolation of sialogogic peptide from bovine hypothalamic tissue and its characterization as Substance P.J. Biol. Chem., $245: 4784-4790.1970$.

23) Chapponi AM, Favrod-coune CA, Gaillard RC, Muller AF. Binding and activation properties of angiotensin II in dispersed rat anterior pituitary cells. Endocrinology, $110: 1043-1045$. 1982.

24) Chen FM, Printz MP. Chronic estrogen treatment reduces angiotensin II receptors in the antetior pituitary. Endocrinology, $113: 1503-$ 1509. 1983.

25) Cheng $K$, Chan W W-S, Barreto A, Convey EM, Smith RG. The synergistic effects of His-DTrp-Ala-Trp-D-Phe-Lys- $\mathrm{NH}_{2}$ on growth hormone $(\mathrm{GH})$-releasing factor-stimulated $\mathrm{GH}$ release and intracellular adenosine 3, 5'-monophosphate accumulation in rat primary pituitary cell culture. Endocrinology, $124: 2791^{-}$ 2798. 1989.

26) Cheng K, Chan W W-S, Butler B, Barreto A, Smith RG. Evidence for a role of protein kinase-C in His-D-Trp-Ala-Trp-D-Phe-Lys$\mathrm{NH}_{2}$-induced grow th hormone release from rat primary pituitary cells. Endocrinology, 129: 3337-3342. 1991.

27) Chihara K, Arimura A, Coy DH, Schally AV. Studies on the interaction of endorphine, substance $P$, and endogenous somatostatin in growth hormone and prolactin release in rats. Endocrinology, 102 : 281-290. 1978.

28) Ch'ng JLC, Christofides ND, Anand P, Gibson SJ, Allen YS, Su HC, Tatemoto K, Morrison JFB, Polak JM, Bloom SR. Distribution of galanin immunoreactivity in the central nervous system and the responses of galanin-containing neuronal pathways to injury. Neurosci., $16: 343-345.1985$.

29) Ciofi P, Croix D, Tramu G. Coexistence of hGHRF and NPY immunoreactivities in neurons of the arcuate nucleus of the rat. Neuroendocrinology, $45: 425-458.1987$.

30) Ciofi P, Tramu G, Bloch B. Comparative immunohistochemical study of the distribution of neuropeptide $\mathrm{Y}$, grow th hormone-releasing factor and the carboxy terminus of precursor protein GHRF in the human hypothalamic in- 


\section{神経ペプチドと成長ホルモン分泌}

fundibular area. Neuroendocrinology, $51: 429-$ 436. 1990.

31) Codd EE, Shu AYL, Walker RF. Bìnding of a grow th hormone releasing hexapeptide to specific hypothalamic and pituitary binding sites. Neuropharmacology, $28: 1139-1144.1989$.

32) Convey EM, Tucker HA, Smith VG, Zolman J. Bovine prolactin, growth hormone, thyroxine and corticoid response to thyrotropin-releasing hormone. Endocrinology, 92 : 471-476. 1973.

33) Croom Jr WJ, Leonard ES, Baker PK, Kraft LA, Ricks CA. The effects of synthetic growth hormone releasing hexapeptide BI 679 on serum growth hormone levels and production in lactating dairy cattle. J. Dairy Sci., 67 (Suppl) : 109 (Abstr). 1984.

34) Culler MD, Paschall CS. Pituitary adenylate cyclase-activating polypeptide (PACAP) potentiates the gonadotropin-releasing activity of luteinizing hormone-releasing hormone. Endocrinology, 129 : 2260-2262. 1991.

35) Cusan L, Dupont A, Kledzik GS, Labrie F, Coy DH, Shally AV. Potent prolactin and growth hormone releasing activity of more analogues of Met-enkephalin. Nature, 268 : 544-546. 1977.

36) Davis TME, Burrin JM, Bloom SR. Growth hormone $(\mathrm{GH})$ release in response to $\mathrm{GH}$ releasing hormone in man is 3 -fold enhanced by galanin. J. Clin. Endocrinol. Metab., 65 : 1248-1252. 1987.

37) degli Uberti EC, Trasforini G, Margutti A, Rossi R, Ambrosio MR, Pansini R. Stimulation of growth hormone and corticotropin release by angiotensin II in man. Metabolism, 39 : 1063-1067. 1990.

38) Delitala G. Opioid peptides and pituitary function. Basic and clinical aspects. In : Brain Endocrinology. 2nd ed. (Motta M ed.) 217-244. Raven Press. New York. 1991.

39) Denef C, Schramme C, Baes M. Stimulation of growh hormone release by vasoactive intestinal peptide and peptide $\mathrm{PHI}$ in rat anterior pituitary reaggregates. Neuroendocrinology, $40: 88-91.1985$.

40) Devesa J, Lima L, Tresgueres AF. Neuroendocrine control of growth hormone secretion in humans. TEM, 3: 175-183. 1992.

41) Dockray GJ. Immunochemical evidence of cholecystokinin-like peptides in brain. Nature, $264: 568-570.1976$.

42) Doscher ME, Baker PK, Kraft LA, Ricks CA. Effect of a synthetic growth hormone releasing hexapeptide (BI 679) and growth hormone releasing factor (GRF) on serum growth hormone levels in barrows. J. Anim. Sci., 59 (Suppl) : 218 (Abstr). 1984.

43) Eriksson E, Edén S, Modigh K. Importance of Norepinephrine $\alpha 2$-receptor activation for morphine-induced rat growth hormone secretion. Neuroendocrinology, $33: 91-96.1981$.

44) Fahrenkrug J. Vasoactive intestinal polypeptide : Measurement, distribution and putative neurotransmitter function. Digestion, 19 : 149-169. 1979.

45) Frohman LA, Downs TR, Chomczynski P. Regulation of growth hormone secretion. Frontiers in Neuroendocrinology, $13: 344-405.1992$.

46) Gabriel SM, Milbury CM, Nathanson JA, Martin JB. Galanin stimulates rat pituitary growth hormone secretion in vitro. Life Sci., 42: 1981-1986. 1988.

47) Gelato MC, Merriam GR. Growth hormone releasing hormone. Ann. Rev. Physiol., 48: 569-591. 1986.

48) Giustina A, Licini $M$, Bussi AR, Girelli A, Pizzocolo G, Schettino M, Negro-Vilar A. Effects of sex and age on the growth hormone response to galanin in healthy human sub. jects. J. Clin. Endocrinol. Metab., $76: 1369-1372$. 1993.

49) Gluckman PD, Marti-Henneberg C, Kaplan SL, Li CH, Grumbach MM. Hormone ontogeny in the ovine fetus. X. The effects of $\beta$-endorphin and naloxone on circulating growth hormone, prolactin, and chorionic somatomammotropin. Endocrinology, $107: 76-80.1980$.

50) Gluckman PD, Breier BH, Davis SR. Physiology of the somatotropic axis with particular reference to the ruminant. J. Dairy Sci, 70 : 442-466. 1987.

51) Goth MI, Lyons CE, Canny BJ, Thorner MO. Pituitary adenylate cyclase activating polypeptide, growth hormone $(\mathrm{GH})$-releasing peptide and $\mathrm{GH}$-releasing hormone stimulate $\mathrm{GH}$ release through distinct pituitary receptors. Endocrinology, $130: 939-944.1992$.

52) Gottschall PE, Tatsuno I, Miyata A, Arimura A. Characterization and distribution of binding sites for the hypothalamic peptide, pituitary adenylate cyclase-activating polypeptide. Endocrinology, $127: 272-277.1990$.

53) Guillaume V, Magnan E, Cataldi M, Dutour A, Sauze N, Renard M, Razafindraibe H. ConteDevolx B, Deghenghi R, Lenaerts $V$, Oliver C. Growth hormone $(\mathrm{GH})$-releasing hormone secretion is stimulated by a new GH-releasing 
hexapeptide in sheep. Endocrinology, 135: 1073-1076. 1994.

54) Hart GR, Ray KP, Wallis M, Mechanisms involved in the effects of TRH on GHRHstimulated growth hormone release from ovine and bovine pituitary cells. Mol. Cell. Endocrinol., 56 : 53-61, 1988.

55) Harvey $S$. Thyrotrophin-releasing hormone: a grow th hormone-releasing factor. J. Endocr., $125:$ 345-358. 1990.

56) Hashizume $T$, Oota $N$, Kanematsu S. Direct effects of VIP on the release of growth hormone from the superfused bovine pituitary in vitro. Jpn. J. Zootech. Sci., 60 : 689-693. 1989.

57) Hashizume T, Kanematsu S. Effects of VIP and GRF on the release of growth hormone in perifused bovine adenohypophysis. Domest. Anim. Endocrinol., $7: 451-456.1990$.

58) Hashizume T, Kanematsu S. Effects of cholecystokinin octapeptide on the release of growth hormone from the perifused bovine pituitary in vitro. Anim. Sci, Technol. (Jpn.), 62 : 243-246. 1991.

59) Hashizume T, Kanematsu S. Effect of cholecystokinin octapeptide on the release of growth hormone in perifused pituitary and hypothalamus of the goat. Anim. Sci. Technol. (Jpn.), 62 : 343-350. 1991.

60) Hashizume T, Kanematsu S. Effect of galanin on the release of growth hormone in perifused bovine pituitary and hypothalamus. Anim. Sci. Technol.(Jpn.), 64 : 553-560. 1993.

61) Hashizume T, Koyama S, Kanematsu S. Effects of pituitary adenylate cyclase-activating polypeptide (PACAP) on the release of growth hormone (GH), luteinizing hormone ( $\mathrm{LH}$ ), and prolactin (PRL) from cultured bovine anterior pituitary cells in vitro. Anim. Sci. Technol. (Jpn.), 65 : 993-998. 1994.

62) Hashizume $T$, Soliman EB, Kanematsu $S$. Effects of pituitary adenylate cyclase-activating polypeptide (PACAP), prostaglandin $\mathrm{E}_{2}$ $\left(\mathrm{PGE}_{2}\right)$ and growth hormone releasing factor (GRF) on the release of growth hormone from cultured bovine anterior pituitary cells in vitro. Domest. Anim. Endocrinol., 11 : 331-337. 1994.

63) Hashizume T, Kanematsu S. Additive effects of pituitary adenylate cyclase-activating polypeptide (PACAP) and growth hormone releasing hormone (GHRH) on the release of growth hormone cultured bovine anterior pituitary cells. Anim. Sci. Technol. (Jpn.), 66 : 330-335. 1995.
64) Hayashi S, Okimura Y, Yagi K, Uchiyama T, Takeshima $Y$, Chihara $K$. Effect of intranasai administration of GHRP on plasma $\mathrm{GH}$ and IGF-I levels in normal men. 2nd International Congress of Neuroendocrinology, BordeauxLac, France, (A bstr), 1990.

65) Hodate $K$, Johke $T$, Ohashi S. Growth hormone, thyrotropin and prolactin responses to simultaneous administration of human growth hormone - releasing factor and thyrotropin releasing hormone in the bovine. Endocrinol. Japon., 32: 375-383. 1985.

66）甫立芓一，家畜における成長ホルモンおよび甲状 腺ホルモンの分泌とその調節機構に関する研究. 日畜会報，59：827-840. 1988.

67) Ilson BE, Jorkasky DK, Curnow RT, Stote RM. Effect of a new synthetic hexapeptide to selectively stimulate growth hormone release in healthy human subjects. J. Clin. Endocrinol. Metab., 69 : 212-214. 1989.

68) Ingram $C D$, Bicknell $\mathrm{RJ}$. Synergistic interaction in bovine pituitary cultures between growth hormone-releasing factor and other hypophysiotrophic factors. J. Endocr., 109 : 6774. 1986.

69) Itoh $\mathrm{N}$, Obata $\mathrm{K}-\mathrm{I}$, Yanaihara $\mathrm{N}$, Okamoto $\mathrm{H}$. Human preprovasoactive intestinal poly. peptide contains a novel PHI-27-like peptide, PHM-27. Nature, 304 : 547-549. 1983.

70) Jacobowitz DM, O'Donohue TL, Chey WY, Chang T-M. Mapping of motilin-immunoreactive neurons of the rat brain. Peptides Fayetteville, $2:$ 479-487. 1981.

71) Jarry H, Leonhardt S, Schmidt WE, Creutzfeldt $\mathrm{W}$, Wuttke $\mathrm{W}$. Contrasting effects of pituitary adenylate cyclase activating polypeptide (PACAP) on in vivo and in vitro prolactin and growth hormone release in male rats. Life Sci., $51:$ 823-830. 1992.

72) Johke T. Effects of TRH on circulating growth hormone, prolactin and triiodothyronine levels in the bovine. Endocrinol. Japon., 25 : 19-26. 1978.

73) Johnson DW, Barnes MA, Akers RM, Pearson RE. A synthetic opioid peptide increases plasma growth hormone and prolactin in Holstein calves. J. Anim. Sci., 71 : 1004-1009. 1993.

74) Kanazawa I, Jessell T. Post mortem changes and regional distribution of substance $P$ in rat and mouse nervous system. Brain Res., 117 : 362-367. 1976.

75）兼松重任・橋爪 力, ウシ下垂体組織加らの成舆 ホルモン分泌調節。栄養生理研報, $37: 191-210$. 
1993.

76) Katakami H, Kato Y, Matsushita N, Shimatsu A, Imura H. Possible involvement of $\gamma$ aminobutyric acid in growth hormone release induced by a Met ${ }^{5}$-enkephalin analog in conscious rats. Endocrinology, 109: 1033-1036. 1981.

77) Katakami H, Kato $Y$, Matsusita N, Hiroto $S$, Shimatsu A, Imura H. Involvement of alphaadrenergic mechanisms in growth hormone release induced by opioid peptides in conscious rats. Neuroendocrinology, $33: 129-135,1981$.

78) Kato $Y$, Chihara $K$, Ohgo S, Iwasaki $Y$, Abe $H$, Imura $\mathrm{H}$. Growth hormone and prolactin release by substance $\mathrm{P}$ in rats. Life Sci., $19: 441-$ 446. 1976.

79) Kato $Y$, Iwasaki $Y$, Iwasaki J, Abe $H$, Yanaihara $N$, Imura $H$. Prolactin release by vasoactive intestinal polypeptide in rats. Endocrinology, $103: 554-558.1978$.

80) Kato Y, Shimatsu A, Matsushita N, Ohta H, Imura $H$. Role of vasoactive intestinal poly peptide (VIP) in regulating the pituitary function in man. Peptides, $5: 389-394.1984$.

81) Kesner JS, Convey EM, Davis SL. Bovine serum hormone concentrations after thyroprotein and thyrotropin releasing hormone. J. Anim. Sci., 44 : 784-790. 1977.

82) Kimura F, Hashimoto R, Kawakami M. The stimulatory effect of cholecystokinin implanted in the medial preoptic area on luteinizing hormone secretion in the ovariectomized estrogen-primed rat. Endocrinol. Japon., 30 : 305-309. 1983.

83) Köves K, Arimura A, Somogyvári-Vigh A, Vigh S, Miller J. Immunohistochemical demonstration of a novel hypothalamic peptide, pituitary adenylate cyclase-activating polypeptide, in the ovine hypothalamus. Endocrinology, $127: 264-271.1990$.

84) Kraft LA, Baker PK, Doscher ME, Ricks CA. Effects of a synthetic growth hormone releasing hexapeptide on serum growth hormone levels in steers. J. Anim. Sci., 59 (Suppl) : 218 (Abstr). 1984.

85) Langevin H, Emson PC. Distribution of substance $P$, somatostatin and neurotensin in the hypothalamus. Brain Res., 246 : 65-69. 1982.

86) Lapierre H, Petitclerc D, Pelletier G, Dubreuil P, Morisset J, Gaudreau P, Couture Y, Brazeau P. Synergism and diurnal variations of human growth hormone-releasing factor $(1-29) \mathrm{NH}_{2}$ and thyrotropin-releasing factor on growth hormone release in dairy calves. Domest. Anim. Endocrinol., 4 : 207-214. 1987.

87) Leshin LS, Rund LA, Thompson FN, Mahaffey MB, Chang WJ, Byerley DJ, Kiser TE. Serum prolactin and growth hormone responses to naloxone and intracerebral ventricle morphine administration in heifers. J. Anim. Sci., 68 : 1656-1665. 1990.

88) Leshin LS, Barb CR, Kiser TE, Rampacek GB, Kraeling RR. Growth hormone-releasing hormone and somatostatin neurons within the porcine and bovine hypothalamus. Neuroendocrinology, 59 : 251-264. 1994.

89) Lind RW, Swanson LW, Bruhn TO, Ganten D. The distribution of angiotensin II-immunoreactive cells and fibers in the paraventriculo-hy pophysial system of the rat. Brain Res., 338 : 81-89. 1985.

90) Lind RW, Swanson LW, Ganten D. Organization of angiotensin II immunoreactive cells and fibers in the rat central nervous system. Neuroendocrinology, $40: 2-24.1985$.

91) Loche S, Cella SG, Puggioni R, Stabilini L, Pintor C, Müller EE. The effects of galanin on growth hormone secretion in children of normal and short stature. Pediatr. Res., $26: 316$ -319. 1989.

92) Maiter DM, Hooi SC, Koenig JI, Martin JB. Galanin is a physiological regulator of spontaneous pulsatile secretion of growth hormone in the male rat. Endocrinology, 126:1216-1221. 1990.

93) Malakey WB, O'Dorisio TM, Kennedy M, Cataland $S$. The influence of vasoactive intestinal polypeptide and cholecystokinin on prolactin release in rat and human monolayer cultures. Life Sciences, 28 : 2489-2495, 1981.

94) Matsumura M, Yamanoi A, Yamamoto S, Mori $\mathrm{H}$, Saito $\mathrm{S}$. In vivo and in vitro effects of cholecystokinin octapeptide on the release of growth hormone in rats. Horm. metabol. Res., $16: 626-630.1984$.

95) Matsushita N, Kato Y, Katakami H, Shimatsu A, Yanaihara N, Imura H. Stimulation of growth hormone release by vasoactive intestinal polypeptide from human pituitary adenomas in vitro. J. Clin. Endocrinol. Metab., 53 : 1297-1300. 1981.

96) McDonald JK, Lumpkin MD, Swanson WK, McCann SM. Neuropeptide $Y$ affects secretion of luteinizing hormone and growth hormone in ovariectomized rats. Proc. Natl. Acad. Sci. USA., $82: 561-564.1985$. 
97) Meister B, Scanlon MF, Hökfelt T, Occurrence of galanin-like immunoreactivity in growth hormone-releasing factor (GRF)-containing neurons of the monkey (Macaca fascicularis) infundibular nucleus and median eminence. Neurosci. Lett., 119 : 136-139, 1990.

98) Miki N, Ono M, Shizume K $\alpha$-adrenergic mechanisms stimulate rat grow th hormone release via growth hormone releasing factor (GRF). Endocrinology, 114 : 1950-1952. 1984.

99) Miyata A, Arimura A, Dahl RR, Minamino N, Uehara A, Jiang L, Culler MD, Coy DH. Isolation of a novel 38 residue-hypothalamic poly. peptide which stimulates adenylate cyclase in pituitary celis. Biochem. Biophy. Res. Commun., $164:$ 567-574. 1989.

100) Miyata A, Jiang L, Dahl RD, Kitada C, Kubo K, Fujino M, Minamino N, Arimura A. Isolation of a neuropeptide corresponding to the $\mathrm{N}$-terminal 27 residues of the pituitary adenylate cyclase activating polypeptide with 38 residues (PACAP 38). Biochem. Biophy. Res. Commun., $170: 643-648.1990$.

101) Momany FA, Bowers CY, Reynolds GA, Hong $A$, Newlander K. Conformational energy studies and in vitro and in vivo activity data on growth hormone-releasing peptides. Endocrinology, $114: 1531-1536.1984$.

102) Morley JE, Melmed S, Briggs J, Carlson HE, Hershman JM, Solomon TE, Lamers C, Damassa DA. Cholecystokinin octapeptide releases growth hormone from the pituitary in vitro. Life Sciences, 25 : 1201-1206. 1979.

103) Mukherjee A, Kulkarni P, McCann SM, NegroVilar A. Evidence for the presence and characterization of angiotensin II receptors in rat anterior pituitary membranes. Endocrinology, $110: 665-667.1982$.

104) Müller EE. Neural control of somatotropic function. Physiol. Rev., 67 : 962-1053. 1987.

105) Murakami $Y$, Kato $Y$, Koshiyama $H$, Inoue $T$, Yanaihara N, Imura $\mathrm{H}$. Galanin stimulates grow th hormone $(\mathrm{GH})$ secretion via $\mathrm{GH}$-releas ing factor (GRF) in conscious rats. Eur. J. Pharmcol, 136: 415-418. 1978.

106) Murakami $Y$, Kato $Y$, Shimatsu A, Koshiyama H, Hattori N, Yanaihara N, Imura H. Possible mechanisms involved in growth hormone secretion induced by galanin in the rat. Endocrinology, $124:$ 1224-1229. 1989.

107) O'Donohue TL, Beinfeld MC, Chey WY. Chang T-M, Nilaver G, Zimmerman EA, Yajima $\mathrm{H}$, Adachi H, Poth M, Dewitt RP, Jacobowitz DM.
Identification, characterization and distribution of motilin immunoreactivity in the rat central nervous system. Peptides Fayetteville, $2: 467-477.1981$.

108) Ogawa N, Mizuno S, Mori A, Nukina I, Yanaihara N. Properties and distribution of vasoactive intestinal polypeptide receptors in the rat brain. Peptides, $6: 103-109.1985$.

109) Ogwuegubu SO, Hashizume T, Kanematsu $S$. Effect of vasoactive intestinal peptide on the release of growth hormone in perifused pituitary and hypothalamus of the goat. Domest. Anim. Endocrinol., 8 : 29-35. 1990.

110) Osuga $\mathrm{Y}$, Mitsuhashi N, Mizuno M. In vivo effect of pituitary adenylate cyclase activating polypeptide 38 (PACAP38) on the secretion of luteinizing hormone $(\mathrm{LH})$ in male rats. Endocrinol. Japon., 39 : 153-156. 1992.

111) Ottlecz A, Samson WK, McCann SM. Galanin: Evidence for a hypothalamic site of action to release growth hormone. Peptides, $7: 51-53$. 1986.

112) Ottlecz A, Snyder GD, McCann SM. Regulatory role of galanin in control of hypothalamicanterior pituitary function. Proc. Natl. Acad. Sci. USA, 85 : 9861-9865. 1988.

113) Palkovits M. Neuropeptides in brain. In : Frontiers in Neuroendocrinology vol. 10. (Martini L, Ganong WF eds.) 1-44. Raven Press. New York. 1988.

114) Patel YC, Srikant CB. Somatostatin mediation of adenohypophysial secretion. Ann. Rev. Physiol., 48 : 551-567. 1986.

115) Rehfeld JF. Localization of gastrins to neuroand adenohypophysis. Nature, 271:771-773. 1978.

116) Reid IA. Actions of angiotensin II on the brain : mechanisms and physiologic role. Am. J. Physiol., 246 : F533-F543. 1984.

117) Renner $U$, Brockmeier S, Strasburger $\mathrm{CJ}$, Lange M, Schopohl J, Müller OA, Werder KV, Stalla GK. Growth hormone (GH)-releasing peptide stimulation of $\mathrm{GH}$ release from human somatotroph adenoma cells : Interaction with GH-releasing hormone, thy rotropin-releasing hormone, and octreotide. J. Clin. Endocrinol. Metab., 78 : 1090-1096. 1994.

118) Rettori V, Milenkovic L, Aguila MC, McCann SM. Physiologically significant effect of neuropeptide $Y$ to suppress growth hormone release by stimulating somatostatin discharge. Endocrinology, $126: 2296-2301.1990$.

119) Rivier C, Vale W, Ling N, Brown M, Guillemin 
R. Stimulation in vivo of the secretion of prolactin and growth hormone by beta-endorphin. Endocrinology, $100: 238-241.1977$.

120) Rivier C, Brown M, Vale W. Effect of neurotensin, substance $P$ and morphine sulfate on secretion of prolactin and growth hormone in the rat. Endocrinology, $100: 751-754.1977$.

121) Robberecht $W$, Denef $C$. Stimulation and inhibition of pituitary growth hormone release by angiotensin II in vitro. Endocrinology, 122 : 1496-1504. 1986.

122) Rökaeus $\AA$, Melander $T$, Hökfelt $T$, Lundberg JM, Tatemoto $K$, Carlquist $M$, Mutt V. A galanin-like peptide in the central nervous system and intestine of the rat. Neurosci. Lett., $47: 161-166,1984$.

123) Said SI, Mutt V. Polypeptide with broad biological activity: isolation from small intestine. Science, NY, $169: 1217-1218.1970$.

124) Said SI, Porter JC. Vasoactive intestinal polypeptide: release into hypophyseal portal blood. Life Sci., 24 : 227-230. 1979.

125) Said SI. Vasoactive intestinal peptide (VIP). Peptides, 5 : 143-150. 1984.

126) Said SI. Vasoactive intestinal peptide. J. Endocrinol. Invest., 9 : 191-200. 1986.

127) Saito A, Sankaran H, Goldfine ID, Williams JA. Cholecystokinin receptors in the brain : Characterization and distribution. Science, 208: 1155-1156. 1980.

128) Samson WK, Lumpkin MD, McCann SM. Motilin stimulates growth hormone release in vitro. Brain Res. Bull, 8 : 117-121. 1982.

129) Samson WK, Lumpkin MD, Nilaver G, McCann SM. Motilin : a novel growth hormone releasing agent. Brain Res. Bull., 12 : 57-62. 1984.

130) Sartor O, Bowers CY, Chang D. Parallel studies of His-DTrp-Ala-Trp-DPhe-Lys- $\mathrm{NH}_{2}$ and human pancreatic growth hormone-releasing factor-44- $\mathrm{NH}_{2}$ in rat primary pituitary cell monolayer culture. Endocrinology, 116:952957. 1985.

131) Sato $M$, Takahara J, Niimi M, Tagawa $R$, Irino $\mathrm{S}$. Characterization of the stimulatory effect of galanin on growth hormone release from the rat anterior pituitary. Life Sci, 48 : 1639-1644. 1991.

132) Sawangjaroen $K$, Curiewis JD. Effects of pituitary adenylate cyclase activating poly peptide (PACAP) and vasoactive intestinal polypeptide (VIP) on prolactin, luteinizing hormone and growth hormone secretion in the ewe. J. Neuroendocrinology, $6: 549-555.1994$.
133) Schally AV, Redding TW, Bowers CY, Barrett JF. Isolation and properties of porcine thyrotropin-releasing hormone. J. Biol. Chem., $244:$ 4077-4088. 1969.

134) Sheppard MC, Kronheim S, Pimstone BL. Effect of substance $P$, neurotensin and the enkephalins on somatostatin release from the rat hypothalamus in vitro. J. Neurochem., 32 : 647649. 1979.

135) Shimatsu A, Kato $Y$, Matsushita N, Katakami, $\mathrm{H}$, Yanaihara $\mathrm{N}$, Imura $\mathrm{H}$. Immunoreactive vasoactive intestinal polypeptide in rat hypophysial portal blood. Endocrinology, 108 : 395-398. 1981.

136) Shimatsu A, Kato $Y$, Inoue $T$, Christofides ND, Bloom SR, Imura $H$. Peptide histidine isoleucine- and vasoactive intestinal polypeptide-like immunoreactivity coexist in rat hypophysial portal blood. Neurosci. Lett., 43 : 259-262. 1983.

137) Sims KB, Hoffman DL, Said SI, Zimmerman EA. Vasoactive intestinal polypeptide (VIP) in mouse and rat brain : an immunohistochem. ical study. Brain Res., $186: 165-183.1980$.

138) Skofitsch G, Jacobowitz DM. Immunohistochemical mapping of galanin-like neurons in the rat central nervous system. Peptides, 6 : 509-546. 1985.

139) Smith VG, Convey EM. TRH-stimulation of prolactin release from bovine pituitary cells (38745). Proc. Soc. Exp. Biol. Med., 149: 70-74. 1975.

140) Soliman EB, Hashizume $T$, Kanematsu $S$. Effect of growth hormone (GH)-releasing peptide (GHRP) on the release of GH from cultured anterior pituitary cells in cattle. Endocrine $\mathrm{J}$., $41: 585-591.1994$.

141) Soliman EB, Hashizume $T$, Kanematsu $S$. The combined effect of PACAP,GHRH, and SRIF on bovine $\mathrm{GH}$ release in vitro. Anim. Sci. Technol. (Jpn.), $66:$ 130-133. 1995.

142) Soliman EB, Hashizume $T$, Ohashi $S$, Kanematsu S. The interactive effects of VIP, PHI, GHRH and SRIF on the release of growth hormone from cultured adenohypophysial cells in cattle. Endocrine J., 42. in press, 1995.

143) Soliman EB, Hashizume $T$, Kanematsu S. Effect of angiotensin II on the release of grow th hormone from cultured anterior pituitary cells in cattle. Anim. Sci. Technol. (Jpn.), (submitted for publication), 1995.

144) Spencer GSG, Berry C, Johnston S. Neuroendocrine regulation of growth hor- 
mone secretion in sheep. IV. Central and peripheral cholecystokinin. Domest. Anim. Endocrinol., $8: 555-563.1991$.

145) Spengler $D$, Waeber $C$, Pantaloni $C$, Holsboer $F$, Bockaert J, Seeburg PH, Journot L. Differential signal transduction by five splice variants of the PACAP receptor. Nature, $365: 170-175$. 1993.

146) Spiess J, Rivier J, Vale W. Characterization of rat hypothalamic growth hormone-releasing factor. Nature, 303:532-535, 1983.

147) Steele MK, Negro-Vilar A, McCann SM. Effect of angiotensin II on in vitro and in vivo release of anterior pituitary hormones in the female rat. Endocrinology, $109: 893-899.1981$.

148) Steele MK, McCann SM, Negro-Vilar A. Modulation by dopamine and estradiol of the central effects of angiotensin II on anterior pituitary hormone release. Endocrinology, $111: 722-729$. 1982.

149) Steele MK. Effects of angiotensins injected into various brain areas on luteinizing hormone release in female rats. Neuroendocrinology, 46 : 401-405. 1987.

150) Strobl JS. Thomas MJ. Human growth hormone. Pharmacol. Rev., 46 : 1-34. 1994.

151) Stubbs WA, Jones A, Edwards CRW, Delitata G, Jeffcoate WJ, Ratler SJ, Besser GM, Bloom SR, Alberti KG. Hormonal and metabolic responses to an enkephalin analogue in normal man. Lancet., 2 : 1225-1227. 1978.

152) Szabo M. TRH and GRF stimulate release of growth hormone through different mechanisms. Am. J. Physiol., 250 : E512-517. 1986.

153) Tanimoto $K$, Tamminga $C A$, Chase $T N$, Nilaver $G$. Intracerebroventricular injection of cholecystokinin octapeptide elevates plasma prolactin levels through stimulation of vasoactive intestinal polyptide. Endocrinology, 121 : 127-132. 1987.

154) Tatemoto $\mathrm{K}$, Mutt $\mathrm{V}$. Isolation and characterization of the intestinal peptice porcine $\mathrm{PHI}$ (PHI-27), a new member of the glucagon-secretion family. Proc. Natl. Acad. Sci. USA, 78 : 6603-6607. 1981.

155) Tatemoto $\mathrm{K}$, Carlquist $\mathrm{M}$, Mutt V. Neuropeptide $Y$ - a novel brain peptide with structural similarities to peptide $\mathrm{YY}$ - and pancreatic polypeptide. Nature Lond, 296:659660. 1982.

156) Tatemoto K, Rőkaeus $\AA$, Jörnvall H, McDonald TJ, Mutt V. Galanin-a novel biologically active peptide from porcine intestine. FEBS.
Lett., $164: 124-128.1983$.

157) Tatemoto K. PHI- a new brain-gut peptide. Peptides, 5 : 151-154. 1984.

158) Thomas WG, Sernia C. Immunocytochemical localization of angiotensinogen and angiotensin II in the rat pituitary. $J$. Neuroendocrinol., $2:$ 297-304. 1990.

159) Torsello A, Sellan $R$, Cella SG, Locatelli V, Mûller EE. Age-dependent modulation by galanin of growth hormone release from rat pituitary cells in culture. Life Sci., $47: 1861$ 1866. 1990.

160) Velkeniers B, Zheng $L$, Kazemzadeh $M$, Robberecht P, Vanhaelst L, Hooghe-Peters EL. Effect of pituitary adenylate cyclase-activating polypeptide 38 on growth hormone and prolactin expression. J. Endocrinology, $143: 1$ 11. 1994.

161) Vijayan E, Samson WK, McCann SM. In vivo and in vitro effects of cholecystokinin on gonadotropin, prolactin, growth hormone and thyrotropin release in the rat. Brain Res., 172 : 295-302. 1979.

162) Vijayan E, Samson WK, Said SI, McCann SM. Vasoactive intestinal peptide: Evidence for a hypothalamic site of action to release growth hormone, luteinizing hormone, and prolactin in conscious ovariectomized rats. Endocrinology, $104:$ :53-57. 1979.

163) Vijayan E, McCann SM, Effects of substance $P$ and neurotensin on growth hormone and thyrotropin release in vivo and in vitro. Life Sci. $26: 321-327.1980$.

164) Vigh S, Arimura A, Köves $K$, SomogyváriVigh A, Sitton J, Fermin CD. Immunohistochemical localization of the neuropeptide, pituitary adenylate cyclase activating polypeptide (PACAP), in human and primate hypothalamus. Peptides, $12: 313-318$. 1991.

165) Vigh $S$, Arimura A, Gottschall PE, Katada $C$, Somogyvári-Vigh A, Childs GW. Cytochemical characterization of anterior pituitary target cells for the neuropeptide, pituitary adenylate cyclase activating polypeptide (PACAP) using biotinylated ligands. Peptides, $14: 59-65.1991$.

166) Walker RF, Codd EE, Barone FC, Nelson AH, Goodwin T, Campbell SA. Oral activity of the growth hormone releasing peptide His-DTrp-Ala-Trp-D-Phe-Lys- $\mathrm{NH}_{2}$ in rats, dogs and monkeys. Life Sci, $47: 29-36.1990$.

167) Weiner RI, Findell PR, Kordon C. Role of clas- 
神経ペプチドと成長ホルモン行緒

sic and peptide neuromediators in the neuroendocrine regulation of $\mathrm{LH}$ and prolactin. In : The Physiology of Reproduction vol.I (Knobil E, Neill JD eds.). 1235-1281. Raven Press. New York. 1988.

168) Williams JA. Cholecystokinin: A hormone and a neurotransmitter. Biomedical Res., 3:
107-121. 1982.

169) Wu D, Chen C, Zhang J, Katoh K, Clarke L. Effects in vitro of new grow th hormone releasing peptide (GHRP-1) on growth hormone secretion from ovine pituitary cells in primary culture. J. Neuroendocrinol., $6:$ 185-190. 1994. 